\title{
The Insulinotropic Action of D-Erythrose
}

\author{
A. Sener, G. Devis, G. Somers, and W. J. Malaisse \\ Laboratory of Experimental Medicine, Brussels University School of Medicine, Brussels, Belgium
}

Summary. D-erythrose $(5.0$ to $20.0 \mathrm{mM})$ stimulates insulin release. This insulinotropic action of erythrose displays several features in common with that of glucose. First, erythrose $(20 \mathrm{mM})$ causes a shift to the left of the sigmoidal curve relating the secretory rate to the glucose concentration, but fails to enhance the maximal response to glucose. Second, the secretory response to erythrose occurs as an early peak followed by a phase of sustained release. Third, erythrose increases the output of lactate from the islets. Last, erythrose inhibits the efflux of ${ }^{45} \mathrm{cal}-$ cium and favours its accumulation in isolated islets. It is suggested that, whether in response to glucose or erythrose, an increase in glycolytic flux may represent the key process involved in the identification of the secretagogue, a subsequent remodelling of calcium fluxes being apparently responsible for the activation of the insulin-releasing system.

Key words: Insulin secretion, glucose, erythrose, calcium, isolated islets.

Our understanding of the mode of action of glucose in the pancreatic B-cell has gained from the comparison between the effects of different carbohydrates upon islet function. The present work indicates that D-erythrose should be added to the list of insulinotropic sugars.

\section{Materials and Methods}

D-erythrose was purchased from Aldrich-Europe (Beerse, Belgium) as a $85 \%(w / w)$ syrup. This preparation of erythrose contained no detectable amount of glucose when tested by the glucose-oxidase method with a sensitivity sufficient to measure one $\mu \mathrm{mol}$ of glucose per mmol of erythrose. Other reagents were identical to those listed in a recent publication [1].

The techniques used for the measurement of insulin release by isolated islets removed from fed rats [2], the net uptake [3] and efflux [4] of ${ }^{45}$ calcium, the output of lactate [5] and oxidation of glucose [6] in the islets were previously described.

The method used for the measurement of insulin release by the isolated perfused rat pancreas was identical to that previously described [7], except that the perfusate consisted of a bicarbonate-buffered solution containing bovine albumin $(5 \mathrm{mg} / \mathrm{ml})$, dextran $(40 \mathrm{mg} / \mathrm{ml})$ and no added blood, as detailed elsewhere [8]. The calcium concentration of the perfusate amounted to $4 \mathrm{mEq} / 1$.

All results are expressed as the mean \pm SEM. In most cases, comparisons of data are restricted to measurements performed with islets derived from the same batch(es).

\section{Results}

Effect of Erythrose upon Insulin Release by Isolated Islets

At a low glucose concentration $(5.6 \mathrm{mM})$, erythrose provoked a dose-related increase in insulin release. The lowest effective concentration of erythrose ranged between 2.5 and $5.0 \mathrm{mM}$ (Fig. 1, left panel). In high concentration $(20.0 \mathrm{mM})$, erythrose stimulated insulin release both in the absence $(p<0.005)$ and presence of glucose, causing a shift to the left of the sigmoidal curve relating the secretory rate to the glucose concentration (Fig. 2, right panel). Ery- 

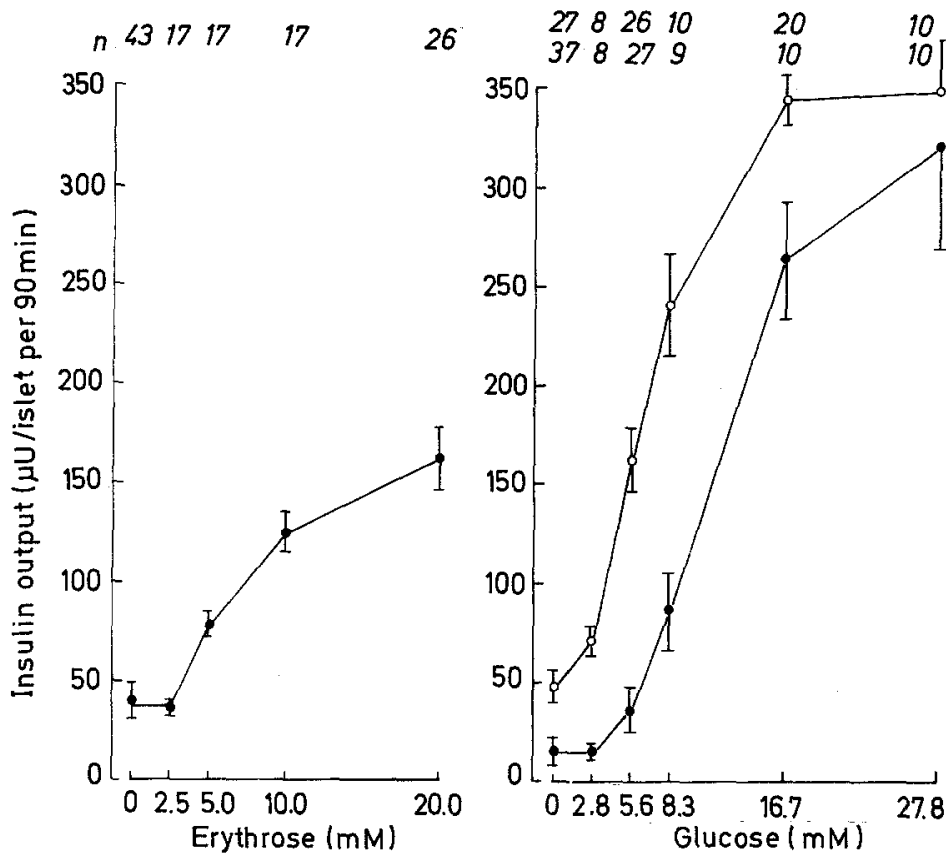

Fig. 1. Left panel: effect of erythrose upon insulin release by isolated islets incubated in the presence of glucose $5.6 \mathrm{mM}$. Right panel: insulin release evoked by glucose in the absence (closed circles) or presence (open circles) of erythrose $(20.0 \mathrm{mM})$. Mean values ( \pm SEM) are shown together with the number of individual determinations $(n)$

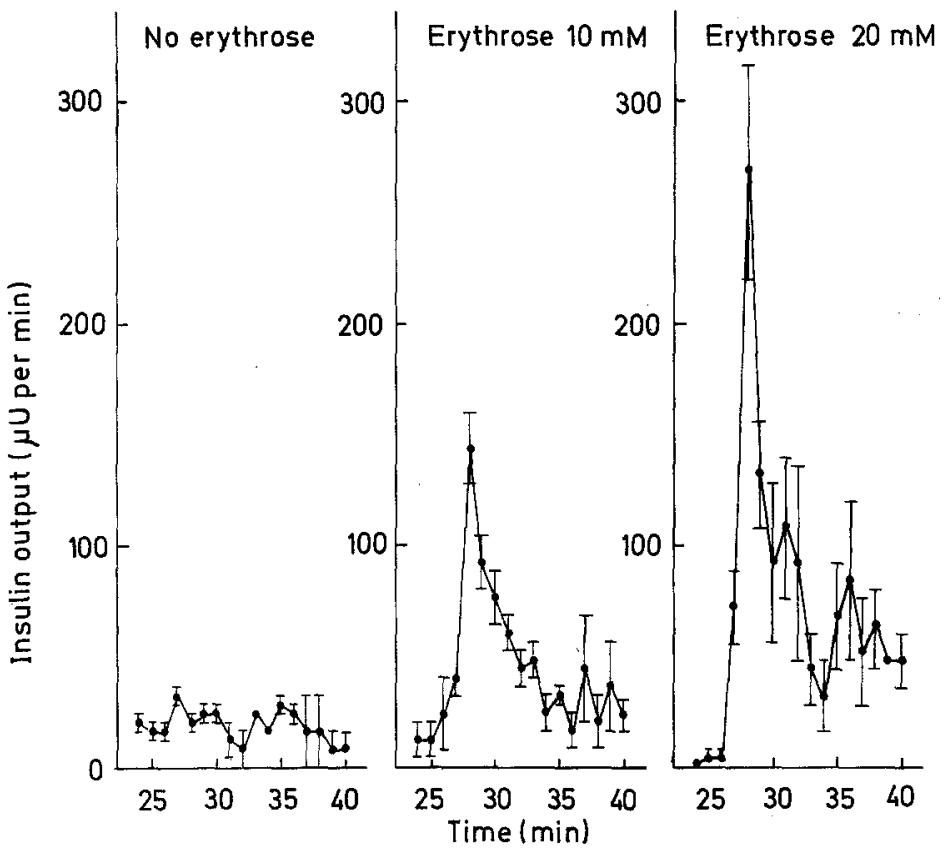

Fig. 2. Effect of erythrose upon insulin release by the isolated perfused rat pancreas. Glucose (2.8 $\mathrm{mM}$ ) was present in all experiments. Erythrose (10 to $20 \mathrm{mM}$ ) was administered from the 25 th $\mathrm{min}$ onwards. Mean values ( \pm SEM) refer to 3 individual experiments in each group

throse failed to significantly increase insulin release $(p>0.6)$ at very high glucose concentration $(27.8$ $\mathrm{mM})$.

\section{Effect of Erythrose upon Insulin Release by the Isolated Perfused Pancreas}

The basal rate of insulin release by the isolated perfused pancreas did not exceed $20 \mu \mathrm{U} / \mathrm{min}$. In low concentration $(2.8 \mathrm{mM})$, glucose failed to stimulate insulin secretion (Fig. 2, left panel). When the pan- creas was exposed to glucose $16.7 \mathrm{mM}$, it responded with an early secretory peak (maximal value observed at the $3 \mathrm{rd}-4$ th min after introduction of glucose: $416 \pm 48 \mu \mathrm{U} / \mathrm{min}, \mathrm{n}=3$ ) followed by a second phase during which insulin release occurred at a mean rate close to $250 \mu \mathrm{U} / \mathrm{min}$ (data not shown).

At a $10.0 \mathrm{mM}$ concentration, erythrose provoked an early secretory response when administered together with glucose $2.8 \mathrm{mM}$ (Fig. 2, middle panel). A biphasic secretory response, analogous to that evoked by glucose, was observed when a higher 
concentration of erythrose $(20.0 \mathrm{mM})$ was administered together with the low amount of glucose $(2.8$ $\mathrm{mM}$; see Fig. 2, right panel). An even greater secretory response to erythrose $(20.0 \mathrm{mM})$ was seen in the presence of glucose $5.6 \mathrm{mM}$ (Fig. 3). These data confirm that glucose and erythrose act synergistically upon the insulin secretory process. It should be noted, however, that after prolonged exposure to both glucose $(5.6 \mathrm{mM})$ and erythrose $(20.0 \mathrm{mM})$, a progressive decrease in insulin output was observed (Fig. 3).

\section{Effect of Erythrose upon ${ }^{45}$ Calcium Handling by Isolated Islets}

At a glucose concentration of $5.6 \mathrm{mM}$, erythrose $(20.0 \mathrm{mM})$ stimulated ${ }^{45}$ calcium net uptake by the islets (Table 1). Relative to the paired control value found in the absence of erythrose, the enhancing effect of erythrose was more marked at the 45 th than the 90th min of incubation. The latter finding suggests that, like its insulinotropic action (see Fig. 3), the stimulatory effect of erythrose upon ${ }^{45}$ calcium net uptake tends to fade during prolonged exposure of the endocrine pancreas to the tetrose.

When islets prelabelled with ${ }^{45}$ calcium were placed in a perifusion chamber and exposed to a perifusate deprived of extracellular calcium and enriched with EGTA $(1.0 \mathrm{mM})$, the addition of erythrose $(20.0 \mathrm{mM})$, in the presence of glucose $(5.6$ $\mathrm{mM}$ ), provoked a rapid fall in ${ }^{45}$ calcium efflux (Fig. 4). Thus, the mean rate of fall in effluent radioactivity, which averaged $-1.01 \pm 0.36 \%$ per min over the last 6 minutes prior to the introduction of erythrose, increased to $-5.32 \pm 0.57 \%$ per min ( $p<0.001$ ) over the ensuing 6 minute period. Incidentally, the influence of erythrose upon ${ }^{45}$ calcium efflux does not correspond to an osmotic effect. Indeed, the addition of erythrose $(20.0 \mathrm{mM})$ at the 45th minute of perifusion provoked the same change in effluent radioactivity whether or not sucrose (also $20.0 \mathrm{mM}$ ) was present in the perifusate administered during the first 45 minute.

\section{Effect of Erythrose upon Islet Metabolism}

As shown in Table 2, glucose provoked a dose-related increase in lactate output from the isolated islets. Erythrose $(20.0 \mathrm{mM})$ significantly stimulated lactate output in the absence of glucose $(p<0.02)$. Erythrose also enhanced the production of lactate $(\mathrm{p}<0.005)$ at intermediate glucose levels $(2.8$ and $9.2 \mathrm{mM})$. At a higher glucose concentration (16.7 $\mathrm{mM})$, the erythrose-induced increase in lactate output was of borderline significance $(0.06<\mathrm{p}<$ $0.05)$.

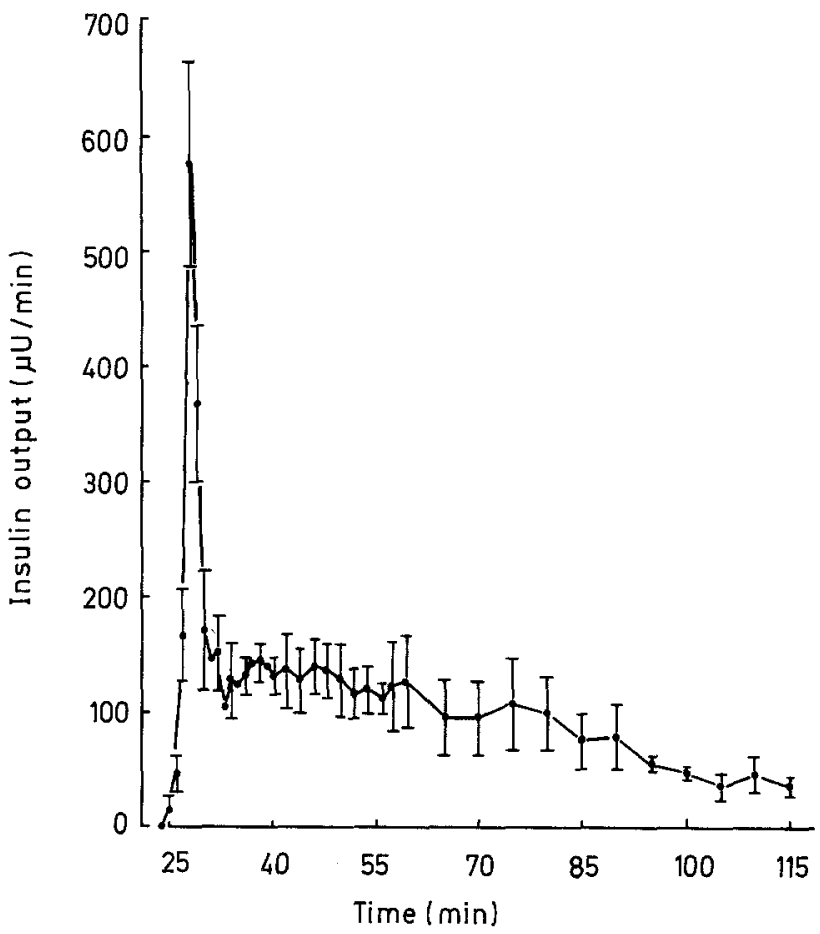

Fig. 3. Combined effect of erythrose $(20 \mathrm{mM})$ and glucose $(5.6 \mathrm{mM})$ upon insulin release by the isolated perfused rat pancreas. Same presentation as in Fig. 2

Table 1. Effect of erythrose $(20 \mathrm{mM})$ upon ${ }^{45}$ calcium net uptake by pancreatic islets incubated in the presence of glucose (5.6 $\mathrm{mM})$. Mean values ( $\pm \mathrm{SEM}$ ) are expressed as $\mathrm{pg}$ /islet and are shown together with the length of incubation ( 45 or $90 \mathrm{~min}$ ), the number of individual determinations (in parentheses), and the significance of difference between control and experimental data as tested by paired comparison

\begin{tabular}{lrl}
\hline Time & Control & Erythrose $20 \mathrm{mM}$ Paired ratio p \\
$(\%)$
\end{tabular}

Table 2. Effect of erythrose $(20 \mathrm{mM})$ upon lactate output by isolated islets. Mean values ( \pm SEM) are shown together with the number of individual determinations. In the last column, the values found in the presence of erythrose are expressed in per cent of the mean control value found, within the same experiment(s) and at the same glucose concentration, in the absence of the tetrose

\begin{tabular}{lcrl}
\hline $\begin{array}{l}\text { Glucose } \\
(\mathrm{mM})\end{array}$ & $\begin{array}{c}\text { Control } \\
\text { (pmol/islet per 90 min) }\end{array}$ & $\begin{array}{l}\text { Erythrose 20 mM Ratio } \\
(\%)\end{array}$ \\
\hline 0 & $21.2 \pm 2.1(8)$ & $42.2 \pm 8.4(9)$ & $219.3 \pm 39.4$ \\
2.8 & $63.8 \pm 8.7(4)$ & $96.0 \pm 11.5(5)$ & $150.6 \pm 18.3$ \\
9.2 & $92.3 \pm 17.4(4)$ & $145.2 \pm 16.8(5)$ & $148.6 \pm 18.1$ \\
16.7 & $108.6 \pm 16.9(5)$ & $141.6 \pm 24.1(5)$ & $132.6 \pm 13.1$ \\
\hline
\end{tabular}




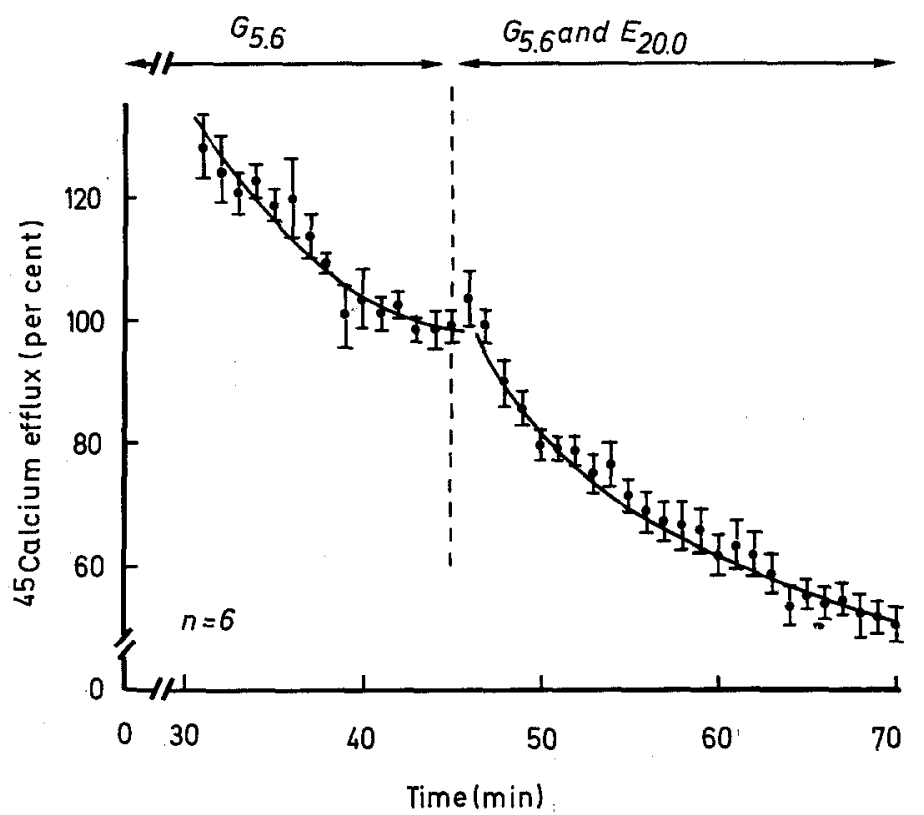

Fig. 4. Effect of erythrose ( $\left.20 \mathrm{mM} ; \mathrm{E}_{20.0}\right)$ upon ${ }^{45}$ calcium efflux from islets perifused with a $\mathrm{Ca}^{2+}$-free medium containing both EGTA (1.0 $\mathrm{mM})$ and glucose $\left(5.6 \mathrm{mM} ; \mathrm{G}_{5.6}\right)$. Mean values $( \pm$ SEM) for ${ }^{45}$ calcium efflux are expressed in per cent of the mean control value observed, within the same experiment, over the $5 \mathrm{~min}$ period prior to the introduction of erythrose (vertical dotted line)
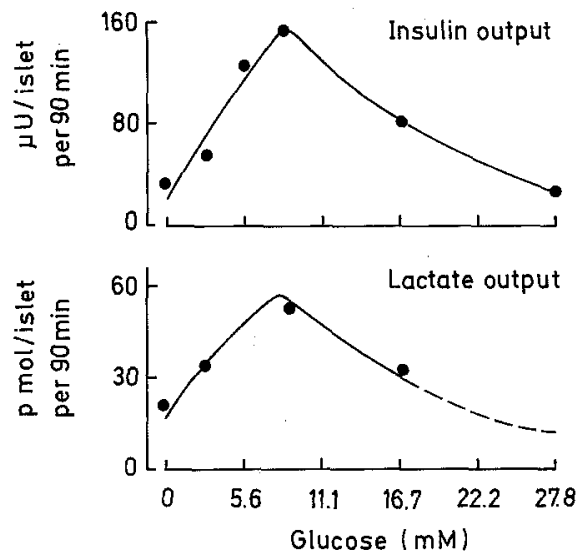

Fig. 5. Comparison between the mean values for the increment in either insulin or lactate output evoked by erythrose $(20 \mathrm{mM})$ in isolated islets exposed for $90 \mathrm{~min}$ to various glucose concentrations

Table 3. Effect of erythrose upon the oxidation of $\left(1{ }^{14} \mathrm{C}\right)$ glucose. Mean values $( \pm$ SEM) are shown together with the number of individual determinations (in parentheses) and the significance of differences attributable to erythrose

\begin{tabular}{lllll}
\hline $\begin{array}{l}\text { Expt. } \\
\text { no. }\end{array}$ & $\begin{array}{l}\text { Glucose } \\
(\mathrm{mM})\end{array}$ & $\begin{array}{l}\text { Control } \\
(\mathrm{pmol} / \text { islet per 120 min) }\end{array}$ & \multicolumn{2}{c}{ Erythrose $(20 \mathrm{mM}) \mathrm{p}$} \\
\hline 1 & 4.1 & $11.4 \pm 1.6(27)$ & $22.6 \pm 2.0(26)$ & $<0.001$ \\
2 & 6.7 & $19.1 \pm 1.2(10)$ & $34.1 \pm 3.1(10)$ & $<0.001$ \\
3 & 20.0 & $50.1 \pm 4.8(20)$ & $54.7 \pm 10.6(19)$ & N. S. \\
\hline
\end{tabular}

Over 90 minutes incubation, there was a highly significant correlation $(\mathrm{r}=0.858 ; \mathrm{n}=8 ; \mathrm{p}<0.01)$ between the mean values for insulin release (Fig. 1, right panel) and lactate output (Table 2), respectively. Moreover, at increasing glucose concentrations, the pattern of changes in insulin output attributable to erythrose was closely similar to that of the erythrose-induced increment in lactate output (Fig. 5). These findings are compatible with the view that the insulinotropic action of the tetrose is concomitant with an increase in glycolytic flux.

The possible influence of erythrose upon glucose metabolism was investigated by examining the effect of the tetrose upon the oxidation of $\left(1-{ }^{14} \mathrm{C}\right)$ glucose to ${ }^{14} \mathrm{CO}_{2}$ (Table 3). At low glucose concentrations (4.1 and $6.7 \mathrm{mM}$ ), erythrose markedly increased the oxidation of $\left(1-{ }^{14} \mathrm{C}\right)$ glucose. At this low glucose level $(4.2 \mathrm{mM})$, erythrose $(20.0 \mathrm{mM})$ also increased the production of ${ }^{3} \mathrm{H}_{2} \mathrm{O}$ from $\left(5-{ }^{3} \mathrm{H}\right)$ glucose, from $34.2 \pm 6.3$ to $69.0 \pm 4.7 \mathrm{pmol} /$ islet per $120 \mathrm{~min}$ $(\mathrm{n}=10$ in each case; $\mathrm{p}<0.001)$. When the glucose concentration was raised to $20.0 \mathrm{mM}$, erythrose failed to significantly increase the oxidation of $\left(1-{ }^{14} \mathrm{C}\right)$ glucose (Table 3$)$.

As shown in Table 4, no significant effect of erythrose upon the oxidation of $\left(\mathrm{U}-{ }^{14} \mathrm{C}\right)$ glucose could be detected when both sugars were used in equimolar amounts and in a range of concentrations (10.0 to $20.0 \mathrm{mM}$ ) previously shown to be sufficiently high for observing, in the presence of other metabolizable sugars, a decrease in the production of ${ }^{14} \mathrm{CO}_{2}$ from $\left(\mathrm{U}-{ }^{14} \mathrm{C}\right)$ glucose $[9,10]$. 
Table 4. Effect of erythrose upon the oxidation of $\left(\mathrm{U}-{ }^{14} \mathrm{C}\right) \mathrm{glu}-$ cose. In each series of experiments, both sugars were used in equimolar amounts. Mean values $( \pm$ SEM) are shown together with the number of individual determinations (in parentheses)

\begin{tabular}{llll}
\hline $\begin{array}{l}\text { Expt. } \\
\text { no. }\end{array}$ & $\begin{array}{l}\text { Glucose } \\
(\mathrm{mM})\end{array}$ & $\begin{array}{l}\text { Erythrose } \\
(\mathrm{mM})\end{array}$ & $\begin{array}{l}\left(\mathrm{U}-{ }^{14} \text { C)glucose oxidation }\right. \\
(\mathrm{pmol} / \text { islet per 120 min) }\end{array}$ \\
\hline 1 & 10.0 & - & $30.1 \pm 2.7(15)$ \\
& 10.0 & 10.0 & $29.5 \pm 1.6(15)$ \\
2 & 20.0 & - & $32.5 \pm 2.0(10)$ \\
& 20.0 & 20.0 & $26.8 \pm 2.9(10)$ \\
\hline
\end{tabular}

Table 5. Effect of glutarate and mannoheptulose upon insulin release evoked by glucose and erythrose. Mean values ( \pm SEM) are shown together with the number of individual determinations (in parentheses) and the significance ( $\mathrm{a}: \mathrm{P}<0.02 ; \mathrm{b}: \mathrm{P}<0.005 ; \mathrm{c}: \mathrm{P}$ $<0.001$ ) of differences between control (first line) and experimental values obtained within the same experiment(s)

\begin{tabular}{|c|c|c|c|c|}
\hline $\begin{array}{l}\text { Glucose } \\
(\mathrm{mM})\end{array}$ & $\begin{array}{l}\text { Erythrose } \\
(\mathrm{mM})\end{array}$ & $\begin{array}{l}\text { Glutarate } \\
(\mathrm{mM})\end{array}$ & $\begin{array}{l}\text { Manno- } \\
\text { heptulose } \\
(\mathrm{mM})\end{array}$ & $\begin{array}{l}\text { Insulin output } \\
(\mu \mathrm{U} / \text { islet per } 90 \mathrm{~min})\end{array}$ \\
\hline 5.6 & - & - & - & $36.1 \pm 6.7(67)$ \\
\hline 5.6 & 10.0 & - & - & $78.7 \pm 9.8(19)^{\mathbf{a}}$ \\
\hline 5.6 & - & 10.0 & - & $50.3 \pm 5.4(27)$ \\
\hline 5.6 & 10.0 & 10.0 & - & $70.8 \pm 7.3(9)^{\mathrm{a}}$ \\
\hline 5.6 & 20.0 & - & - & $109.4 \pm 7.0(47)^{\mathrm{c}}$ \\
\hline 5.6 & 20.0 & 10.0 & - & $95.6 \pm 6.7(30)^{\mathrm{b}}$ \\
\hline 5.6 & 20.0 & - & 13.4 & $18.1 \pm 9.1(17)$ \\
\hline
\end{tabular}

Table 6. Effect of erythrose and glyceraldehyde upon insulin release. Same presentation as in Table 5

\begin{tabular}{lll}
\hline $\begin{array}{l}\text { Erythrose } \\
(\mathrm{mM})\end{array}$ & $\begin{array}{l}\text { Glyceraldehyde } \\
(\mathrm{mM})\end{array}$ & $\begin{array}{l}\text { Insulin output } \\
(\mu \mathrm{U} / \text { islet per } 90 \mathrm{~min})\end{array}$ \\
\hline- & - & $12.9 \pm 8.9(19)$ \\
20.0 & - & $47.2 \pm 9.6(20)^{\mathrm{a}}$ \\
- & 10.0 & $79.5 \pm 7.5(19)^{\mathrm{c}}$ \\
20.0 & 10.0 & $67.4 \pm 7.0(19)^{\mathrm{c}}$ \\
\hline
\end{tabular}

\section{Effect of Metabolic Inhibitors upon Erythrose- Induced Insulin Release}

Erythrose could conceivably be a substrate for the islet enzyme aldose reductase [11]. We have examined, therefore, the influence of a known inhibitor of this enzyme, namely glutaric acid [12], upon the insulinotropic action of erythrose (Table 5). At a glucose concentration of $5.6 \mathrm{mM}$, glutaric acid $(10.0 \mathrm{mM})$ failed to affect significantly the secretion of insulin evoked by erythrose (10.0 and $20.0 \mathrm{mM})$. In the absence of erythrose, but in the presence of glucose $(5.6 \mathrm{mM})$, glutaric acid $(10.0 \mathrm{mM})$ slightly enhanced insulin release, but this effect failed to achieve statistical significance. Likewise, at a 4.2 $\mathrm{mM}$ glucose level, glutaric acid (10.0 mM), which itself slightly reduced erythrose-stimulated $\left(1-{ }^{14} \mathrm{C}\right)$ glucose oxidation to $80.8 \pm 7.9 \%$ of its con- trol value $(25.4 \pm 2.6 \mathrm{pmol} /$ islet per $120 \mathrm{~min} ; \mathrm{n}=$ 11 to 12 ), failed to abolish the enhancing action of the tetrose upon $\left(1-{ }^{14} \mathrm{C}\right)$ glucose oxidation. Thus, in the presence of glutaric acid $(10.0 \mathrm{mM})$, the tetrose $(20.0 \mathrm{mM})$ increased the oxidation of $\left(1-{ }^{14} \mathrm{C}\right)$ glucose $(4.2 \mathrm{mM})$ from $7.4 \pm 1.0$ to $15.3 \pm 1.5 \mathrm{pmol} /$ islet per $120 \min (\mathrm{n}=11$ to $12 ; \mathrm{p}<0.001)$.

As shown in Table 5 (last line), mannoheptulose $(13.4 \mathrm{mM})$ abolished the release of insulin evoked by the combination of glucose $(5.6 \mathrm{mM})$ and erythrose $(20.0 \mathrm{mM})$.

Erythrose failed to enhance the release of insulin evoked by glyceraldehyde (Table 6), at least when each of these two sugars was used in a concentration close to that required for causing, on its own, a nearly optimal secretory response in the present system.

\section{Discussion}

The results illustrated in Figures 1 to 3 indicate that erythrose stimulates insulin release. In a preliminary account [13], Sharoni and Dimant provided data suggesting that erythrose $(30.0 \mathrm{mM})$ may slightly increase insulin output from pieces of rabbit pancreas exposed to glucose $15.0 \mathrm{mM}$. However, because of the hyperglycaemic effect of erythrose in vivo [14], these authors were concerned with a possible inhibitory action of erythrose upon glucose-induced insulin release.

The insulinotropic action of erythrose, as revealed by the present study, displays several features in common with that of glucose. First, like other glucose-mimicking agents $[1,15]$, erythrose displaces to the left the sigmoidal curve relating insulin output to glucose concentration, but fails to significantly increase the rate of secretion observed at very high glucose concentration (Fig. 1, right panel). Second, the release of insulin evoked by erythrose, like that evoked by glucose, is characterized by a biphasic pattern (Figs. 2 and 3). Third, in both cases, the secretory response may be mediated through the accumulation of calcium in a critical site of the B-cell (Table 1), a process itself apparently caused, in part at least, by a reduction in the outward transport of calcium across the B-cell membrane (Fig. 4). Finally, the insulinotropic action of erythrose, like that of glucose and other sugars [9, 16], coincides with an increase in glycolytic flux (Table 2 and Fig. 5).

Our metabolic data do not elucidate the pattern of erythrose metabolism in the islets. However, they suggest that erythrose exerts a dual metabolic effect. First, the increase in lactate output evoked by erythrose in the absence of glucose (Table 2) suggests that the tetrose itself can eventually serve as a sub- 
strate for glycolysis. Second, the increase in the oxidation of $\left(1-{ }^{14} \mathrm{C}\right)$ glucose provoked by erythrose at low glucose concentrations $(4.2$ to $6.7 \mathrm{mM}$, see Table 3) suggests that erythrose may facilitate the metabolism of glucose. Such a dual mode of action would also explain why erythrose, in contrast to sugars like glyceraldehyde [9], fails to reduce the output of ${ }^{14} \mathrm{CO}_{2}$ from $\left(\mathrm{U}-{ }^{14} \mathrm{C}\right)$ glucose in the 10.0 to $20.0 \mathrm{mM}$ range (Table 4 ).

The intimate mechanisms by which erythrose (i) is converted to a glycolytic intermediate and (ii) facilitates the metabolism of glucose are both unknown. Our findings with glutaric acid suggest that the reaction catalyzed by the enzyme aldose-reductase does not play a major role in such processes. It may be that erythrose is phosphorylated and then converted to hexose-phosphate through a transketolase reaction [17]. Alternatively, erythrose may be first converted to fructose, and then phosphorylated [18]. In both cases, the insulinotropic action of erythrose would be largely dependent on adequate hexose phosphorylation, a situation which would account both for the inhibitory effect of mannoheptulose upon the release of insulin evoked by the combination of glucose and erythrose (Table 5), and the failure of erythrose to enhance glyceraldehyde-induced insulin release (Table 6).

Whatever the exact mode of interference of erythrose upon islet metabolism, our measurements of lactate output clearly indicate that the insulinotropic action of the tetrose coincides with an increase in glycolytic flux. As such, the present data are compatible with the view that glycolysis represents the key component of the sensor device through which different sugars, including glucose itself [19], are identified by the pancreatic B-cell as insulinotropic agents.

Acknowledgements. This work was supported in part by grants from the Belgian Funds for Scientific Medical Research and a contract of the Belgian Ministry of Scientific Policy within the framework of the association Euratom - Universities of Brussels and Pisa. The authors are grateful to G. De Pauw, M. Mahy, G. Schoonjans, J. Schoonheydt and M. Urbain for technical assistance, and to B. Noël for secretarial help.

\section{References}

1. Malaisse, W.J., Herchuelz, A., Levy, J., Sener, A., Pipeleers, D. G., Devis, G., Somers, G., Van Obberghen, E.: The stimulus-secretion coupling of glucose-induced insulin release. XIX. The insulinotropic effect of glyceraldehyde. Mol. Cell. Endocrinol. 4, 1-12 (1976)

2. Malaisse, W.J., Brisson, G., Malaisse-Lagae, F.: The stimulus-secretion coupling of glucose-induced insulin release. I. Interaction of epinephrine and alkaline earth cations. J. Lab. Clin. Med. 76, 895-902 (1970)
3. Malaisse-Lagae, F., Malaisse, W. J.: Stimulus-secretion coupling of glucose-induced insulin release. III. Uptake of ${ }^{45} \mathrm{cal}-$ cium by isolated islets of Langerhans. Endocrinology 88, 72-80 (1971)

4. Malaisse, W. J., Brisson, G. R., Baird, L. E.: Stimulus-secretion coupling of glucose-induced insulin release. X. Effect of glucose on ${ }^{45} \mathrm{Ca}$ efflux from perifused islets. Am. J. Physiol. 224, 389-394 (1973)

5. Sener, A., Malaisse, W. J.: Measurement of lactic acid in nanomolar amounts. Reliability of such a method as an index of glycolysis in pancreatic islets. Biochem. Med. 15, 34-41 (1976)

6. Malaisse, W. J., Sener, A., Mahy, M.: The stimulus-secretion coupling of glucose-induced insulin release. XVIII. Sorbitol metabolism in isolated islets. Eur. J. Biochem. 47, 365-370 (1974)

7. Van Obberghen, E., Somers, G., Devis, G., Vaughan, G.D., Malaisse-Lagae, F., Orci, L., Malaisse, W. J.: Dynamics of insulin release and microtubular-microfilamentous system. I. Effect of cytochalasin B. J. Clin. Invest. 52, 1041-1051 (1973)

8. Leclercq-Meyer, V., Marchand, J., Leclercq, R., Malaisse, W.J.: Glucagon and insulin release by the in vitro perfused rat pancreas. Influence of the colloid composition of the perfusate. Diab. Métab. 2, 57-65 (1976)

9. Malaisse, W.J., Sener, A., Levy, J., Herchuelz, A.: The stimulus-secretion coupling of glucose-induced insulin release. XXII. Qualitative and quantitative aspects of glycolysis in isolated islets. Acta Diabet. Lat. 13, in press (1976)

10. Hellman, B., Idahl, L.-Å., Lernmark, $\AA$., Sehlin, J., Täljedal, I.-B.: The pancreatic $\beta$-cell recognition of insulin secretagogues. Comparisons of glucose with glyceraldehyde isomers and dihydroxyacetone. Arch. Biochem. Biophys. 162, $448-457$ (1974)

11. Hayman, S., Kinoshita, J.H.: Isolation and properties of lens aldose reductase. J. Biol. Chem. 240, 877-882 (1965)

12. Gabbay, K.H., Tze, W. J.: Inhibition of glucose-induced release of insulin by aldose reductase inhibitors. Proc. Natl. Acad. Sci. USA 69, 1435-1439 (1972)

13. Sharoni, Y., Dimant, E.: Insulin release from pieces of pancreas incubated in vitro in the presence of D-erythrose. FEBS Letters 18, 89-91 (1971)

14. Dimant, E., Levy, J., Graziani, J., Sharoni, Y.: D-erythrose induced hyperglycemia. Isr. J. Med. Sci. 8, 258-261 (1972)

15. Malaisse, W.J.: Insulin secretion: multifactorial regulation for a single process of release. Diabetologia 9, 167-173 (1973)

16. Sener, A., Levy, J., Malaisse, W.J.: The stimulus-secretion coupling of glucose-induced insulin release. XXIII. Does glycolysis control calcium transport in the B-cell? Biochem. J. 156, 521-525 (1976)

17. Batt, R. D., Dickens, F., Williamson, D. H.: Tetrose metabolism. II. The utilization of tetroses and tetritols by rat tissues. Biochem. J. 77, 281-294 (1960)

18. Fluharty, A. L., Bailey, G., Giudici, T. A.: Conversion of Derythrose to $\mathrm{D}$-fructose by rat liver homogenates. Arch. Biochem. Biophys. 118, 12-22 (1967)

19. Malaisse, W.J., Sener, A., Koser, M., Herchuelz, A.: Stimulus-secretion coupling of glucose-induced insulin release. XXIV. Metabolism of $\alpha$ - and $\beta$-D-glucose in isolated islets. J. Biol. Chem. 251, 5936-5943 (1976)

Received: September 25, 1976, and in revised form:

December 22, 1976

Dr. W. J. Malaisse

Laboratory of Experimental Medicine

Boulevard de Waterloo 115

B-1000 Brussels, Belgium 